\title{
Enige opmerkingen over de herkomst en betekenis van artikel 1612 Oud Burgerlijk Wetboek
}

\section{Inleiding}

Art. 1612 lid 1 Oud Burgerlijk Wetboek (OBW) luidde als volgt: 'door verkoop van het verhuurde wordt eene te voren aangegane huur niet verbroken, ten ware dit bij de verhuring mogt voorbehouden zijn.' De bepaling hield kort gezegd in dat koop geen huur brak. Bijna ieder aspect van dit adagium was volgens de toen heersende leer onnauwkeurig. Het huurcontract tussen verhuurder en huurder bleef ondanks de verkoop door de verhuurder 'gewoon' bestaan. Niet de koop was het moment van de verbreking van het huurcontract, maar de eigendomsoverdracht die op de koop volgde. Dit gold overigens niet alleen voor koop, maar voor elke overdracht. ${ }^{1}$ Art. 1612 leek een breuk te vormen met het Romeinse recht, dat als uitgangspunt kende: koop breekt huur. Keizer Alexander Severus bepaalde in 234: voor de koper van een perceel grond is het niet noodzakelijk een pachter aan wie de vorige eigenaar het heeft verpacht, te handhaven, tenzij hij met dit beding heeft ingeste md. ${ }^{2}$ Toch was het verschil tussen het Romeinse recht en het Nederlandse recht van 1838 niet zo groot, als op het eerste gezicht leek. Dit zal uit het vervolg van deze bijdrage blijken.

De gedachte was dat koop breekt geen huur uit het 'Germaanse recht' stamde. Volgens de Leidse hoogleraar in het oud-vaderlandse recht, S.J. Fockema Andreae (1844-1921), was deze regel echter niet voor oorspronkelijk Germaans te houden. ${ }^{3}$ De Nijmeegse hoogleraar F.F.X. Cerutti (1915-1970) nuanceerde dat weer. De rechtsgeschiedenis van art. 1612 OBW

1 Zie P.A.J. Losecaat Vermeer, 'Het bijzondere deel van het Verbintenissenrecht van 1838 en heden', in: P. Scholten en E.M. Meijers (red.), Gedenkboek Burgerlijk Wetboek 1838-1938,Zwolle: W.E.J. Tjeenk Willink 1938, p. 521; P.W. Kamphuisen, Mr C. Asser's Handleiding tot de beoefening van het Nederlandsch Burgerlijk Recht, Derde deel - Verbintenissenrecht, derde stuk: Bijzondere overeenkomsten,Zwolle: W.E.J. Tjeenk Willink 1960, p. 260, p. 263, p. 265, p. 271; F.F.X. Cerutti, 'De rechtsgeschiedenis van art. 1612 BW (jo 34 Pachtwet)', in: F.F.X. Cerutti, Hoofdstukken uit de Nederlandse Rechtsgeschiedenis, uitgegeven door G.C.J.J. van den Bergh, Nijmegen: GNI 1972, p. 33.

2 C. 4,65,9. Vertaling ontleend aan uitgave van Spruit/Chorus/De Ligt.

3 S.J. Fockema Andreae, Het Oud-Nederlandsch Burgerlijk Recht, I, Haarlem: De Erven Bohn 1906, p. 345. Cerutti en J. Giliss en voor de 'zuidelijke' gebieden zijn veel minder stellig dan Fockema Andreae. Gilissen onderscheidde drie stelsels: 'het Germaansche' (huur gaat voor koop), het op het Romeinse recht teruggaande 'Franse' (koop breekt huur) en het 'gemengde' stelsel. Dit stelsel hield in dat huur voorkoop ging, als het huurcontract voor schepenen was opgemaakt. Dit contract deed een zakelijk recht ontstaan, dat de huurder aan derden kon tegenwerpen. Het gemengde stelsel lag ten grondslag aan art. 1743 Cc. Zie J. Gilissen, "Huur gaat voor koop" in het Oud-Belgische Recht', Tijdschrift voor Rechtsgeschiedenis 1939, p. 317-319. 
was volgens hem een voorbeeld van hoe Germaansrechtelijke en Romeinsrechtelijke elementen naast en tegenover elkaar in de Nederlanden hebben 'gewerkt'. ${ }^{4}$ Het 'Germaanse' recht was in de ogen van Fockema Andreae en Cerutti het inheemse recht tot 1500, het recht dat dus niet of nauwelijks invloed had ondergaan van het Romeinse recht. Zij duidden dit 'Germaanse' of inheemse recht ook wel aan als oud-vaderlands recht. De Hoge Raad heeft in een aantal uitspraken aan het einde van de $19^{\mathrm{e}}$ eeuw en in de eerste helft van de $20^{\mathrm{e}}$ eeuw betoogd dat de uitleg van art. 1612 OBW moest geschieden aan de hand van het oudvaderlandse recht. Al zijn uitspraken bevatten een ongeveer qua formulering gelijke overweging. $\mathrm{Zij}$ luidde als volgt:

'O. daaromtrent, dat waar de wetgever, met afwijking van den aanvankelijk naar art. 1743 van den Code Napoleon gevolgden tekst, ten slotte de tegenwoordig aan het oud-Hollandsche recht ontleende formuleering in art. 1612 B.W. opnam, de beteekenis dier formule geene andere kan zijn dan zij in het oude vaderlandsche recht had (...). ${ }^{5}$

P.W. Kamphuisen (1897-1961) bestreed dat de Nederlandse wetgever van 1838 had willen terugkeren naar dit oud-vaderlandse recht. Het beginsel koop breekt geen huur was 'eenvoudig een reactie, gegrond op overwegingen van billijkheid en algemeen belang, tegen de strikte juridische logica.' Het was volgens hem dan ook onjuist de vragen naar aanleiding van art. 1612 OBW aan de hand van het oud-vaderlandse recht te willen oplossen. ${ }^{6}$

Het bovenstaande 'gekrakeel' is aanleiding voor deze bijdrage. In $\S 2$ schets ik in vogelvlucht de rechtshistorische achtergrond van art. 1612 OBW, beginnend bij het Romeinse recht en eindigend bij het Rooms-Hollandse recht. In $\S 3$ beschrijf ik de achtergrond en codificatiegeschiedenis van deze bepaling in het BW van 1838. In $\S 4$ sta ik stil bij de aard van de rechtspositie van de huurder. Voorts bespreek ik in $\S 5$ naar aanleiding van de schets van de historische achtergrond van art. 1612 OBW het begrippenpaar Romeins- en Germaansrechtelijk aan het einde van de $19^{\mathrm{e}}$ eeuw en in de eerste helft van de $20^{\mathrm{e}}$ eeuw in Nederland. Tot slot volgen in $\S 6$ enkele afrondende opmerkingen.

4 Cerutti, 'De rechtsgeschiedenis van art. 1612 BW', p. 60.

$5 \quad$ HR 5 november 1896, Weekblad van het Recht (W.) 1896/6882, p. 1; HR 5 maart 1897, W. 1907/6937, p. 2; HR 20 april 1906, W. 1906/8368, p. 1; HR 8 december 1922, W. 1922/11044, p. 3; HR 3 oktober 1934, W. 1935/12851, p. 3. Niet alleen bij art. 1612 OBW verwees de Hoge Raad naar het oud-Hollandse recht. Dat gebeurde bijvoorbeeld ook in HR 3 maart 1905, W. 1905/8191 (Blaauboer/Berlips), waarin de Hoge Raad verwierp dat een verbintenis een zakelijk karakter kon krijgen en na een eigendomsoverdracht op de nieuwe eigenaar kwam te rusten. Door een zodanige overgang zou een grote onzekerheid ontstaan ten aanzien van de lasten die op goederen rustten en dat was niet overeen te brengen met het stelsel van openbaarheid, door de wet aangenomen bij de vestiging van zakelijke rechten, 'zooals reeds voor het Oud-Hollandsch recht is opgemerkt door Voet (...) en Groenewegen (...).'

6 Asser/Kamphuisen, Verbintenissenrecht, p. 260, 262 (citaat). Hij bestreed vooral A.P.L. Nelissen, Huur en vervreemding, diss. Leiden, 1880, die het oud-vaderlandse recht als bron van art. 1612 OBW had aangewezen. 


\section{De rechtshistorische achtergrond van art. $1612 \mathrm{OBW}$ in vogelvlucht}

Naar Romeins recht vloeiden uit de huurovereenkomst relatieve rechten en plichten voort. De huurder kon zijn verhuurder aanspreken, indien deze zijn verplichtingen niet nakwam en omgekeerd. Als de verhuurder het verhuurde goed aan iemand anders in eigendom overdroeg tijdens de huurperiode, was de huurder niet in staat zijn recht te handhaven tegen de verkrijger. Hij kon zich hiertegen indekken door de verhuurder te verplichten om bij de nieuwe eigenaar dezelfde rechten te bedingen als hij, huurder, jegens de verhuurder had. Hij kon dan de verhuurder aanspreken met de actio conducti (actie uit huur) die op zijn beurt de nieuwe eigenaar kon aanspreken met de actio venditi (actie uit verkoop) De verhuurder eiste de schade op die hij leed door de actie van de huurder. Gaius zei het zo:

\footnotetext{
'Wie een perceel grond tot vruchttrekking heeft verpacht of een woning aan iemand heeft verhuurd, moet, indien hij om een of andere reden dit perceel of die woning verkoopt, er zorg voor dragen dat het de pachter resp. de huurder ook jegens de koper vrijstaat op dezelfde voorwaarden de vruchten te trekken resp. het huis te bewonen; anders zal deze, als hem dit belet wordt, de actie uit huurtegen hem kunnen instellen.'7
}

De zaak loste zich dus op in schadevergoeding. De nieuwe eigenaar kon nog steeds de huurder uit het huis of van het land zetten. Volgens Fritz Schulz (1879-1957) was de louter verbintenisrechtelijke positie van de huurder 'a glaring illustration of his social and economic dependency'. ${ }^{8}$ Een moderne Romanist als David Johnston heeft echter - onder verwijzing naar een aantal literaire teksten - erop gewezen dat de verhuurder belang had bij 'goede' huurders en bij de continuïteit van de huur. Hij riep daarom op voorzichtig te zijn 'in assuming that the tenant was in practice in a fragile position'. ${ }^{9}$ De positie van de huurder werd in de loop van de (Romeinse) tijd (nog) verder versterkt. Volgens D. 43,16,12 was een pachter niet aansprakelijk, indien hij de koper van een verpacht stuk land niet had toegelaten de grond in bezit te nemen. Hij moest dat dan wel om 'een rechtmatige of aannemelijke reden' (propter iustam et probabilem causam) hebben gedaan. Het feit dat de grond was verpacht of verhuurd, was een dergelijke reden. ${ }^{10}$

Naar het middeleeuwse geleerde recht raakte de rechtspositie van de huurder met steeds meer waarborgen omgeven, ook al bleef het uitgangspunt koop breekt huur (emptio tollit

7 D. 19,2,25,1 (vertaling ontleend aan de uitgave van Spruit/Feenstra en Bongenaar). Zie ook D. 19,1,13,30.

8 F. Schulz, Classical Roman Law, Oxford: Clarendon Press 1951 [reprint 1969], p. 546.

9 D. Johnston, Roman Law in Context, Cambridge: Cambridge University Press 1999 [reprint 2008], p. 62 en 66. Ook Cerutti, 'De rechtsgeschiedenis van art. 1612 BW', p. 34 veronderstelde dat landbouwbelangen (naast de billijkheid) in de Romeinse tijd hadden bijgedragen aan een versterking van de positie van de huurder (pachter).

10 R. Zimmermann, The Law of Obligations. Roman Foundations of the Civilian Tradition, ZuidAfrika/Deventer \& Boston: Juta \& Co and Kluwer 1990 (repr. 1992), p. 380. 
locatum). De positie was zo sterk geworden dat eerder sprake leek te zijn van 'koop breekt geen huur' dan van 'koop breekt huur'. Zo introduceerden de glossatoren aan de hand van D. 43,18,1,3 ${ }^{11}$ onderscheid tussen huur voor een korte en huur voor een lange tijd (locatio conductio ad longum tempus). De scheidslijn tussen de twee huurtypen lag bij 10 jaar. Deze 'lange' huur gaf de huurder een zakelijk recht. ${ }^{12}$ Nog in art. 7 van de Eerste Afdeling in Titel 7 (Van huur van huizen en landen) van het Ontwerp-Van der Linden (1807/1808) was terug te vinden dat een huurovereenkomst niet langer dan voor 10 jaren kon worden aangegaan. De lange huur was geen overeenkomst, maar leverde in dit Ontwerp eveneens een zakelijk recht op. ${ }^{13}$

De Rooms-Hollandse juristen van de $17^{\mathrm{e}}$ eeuw en later hebben zich gekeerd tegen de Romeinsrechtelijke regel dat koop huur breekt. Zij deden daarvoor niet alleen een beroep op de gemeenrechtelijke opvattingen, maar tevens op het in de provincie Holland geldende recht, dat overeenkomsten vertoonde met het gewoonterecht in de omliggende gebieden. Het uitgangspunt was daar koop breekt geen huur. Hugo de Groot (1583-1645) tekende dit uitgangspunt zelfs twee keer op:

'(...) Dan by ons gheeft alle huir eenig eigen recht, als zijnde een bruick van korten tijd: 't welck daer uit blijckt, dat het verhuirde land ofte huis zijnde verkocht, den huirman evenwel sijn huir moet volghen: doch een huirman van land heeft dit recht niet zonder schriftelicke huire (...).'14

'By ons werd verder ghebruickt, dat oock den kooper de huire by sijnen verkooper gemaeckt moet laten volghen, waer van hier vooren is gesproken [zie de hierboven weergegeven tekst] (...).'15

Andere Rooms-Hollandse juristen, zoals Simon Groenewegen van der Made (1613-1652) en S. van Leeuwen (1626-1682), deelden de opvatting van Grotius. Van Leeuwen schreef in zijn beroemde werk Het Rooms-Hollands-Regt:

11 D. 43,18,1,3 had betrekking op het toekennen van een zakelijke actie aan iemand 'die niet [slechts] voor een betrekkelijk geringe tijd de opstalheeft gehuurd'.

12 Cerutti, 'De rechtsgeschiedenis van art. 1612 BW', p. 35-36; E.J.H. Schrage, Koop breekt geen huur. Enkele grepen uit de geschiedenis van het geleerde recht inzake de gevolgen van de vervreemding van een verhuurde zaak, Deventer: Kluwer 1984, p. 14 e.v.; H. Coing, Europäisches Privatrecht (15001800), I, München:C.H. Beck 1985, p. 369-370, p. 457-458; E.J.H. Schrage, 'Sale breaks hire-or does it? Medieval foundations of the Roman-Dutch concept', Tijdschrift voor Rechtsgeschiedenis 1986, $\mathrm{p}$. 294 e.v.; Zimmermann, The Law of Obligations, p. 377 e.v. Volgens Coing en Zimmermann hebben $18 \mathrm{e}-$ eeuwse natuurrechtsjuristen het adagium 'koop breekt huur' scherp gekritis eerd. De verhuurder had door het aangaan van een huurovereenkomst zijn vrijheid om het land te gebruiken en ervan te genieten beperkt. Hij kon daarom geen onbeperkte vrijheid aan een ander overdragen. Zie ook Schrage, Koop breekt geen huur, p. 25-26 over de natuurrechtelijke dissertatie van de Groninger E.J. Witsenborg, De paroemia iuris patrii 'Huur gaat voor koop'(1776).

13 Art. 17 van deze afdeling bevatte de verplichting van de koper van het verhuurde goed de huur gestand te doen. Zie Cerutti, 'De rechtsgeschiedenis van art. 1612 BW', p. 57.

14 H. de Groot, Inleidinge tot de Hollandsche Rechts-Geleerdheid, ed. F. Dovring, H.F.W.D. Fischer, E.M. Meijers, tweede uitgave, Leiden: Universitaire Pers Leiden 1965, II, 44, 9.

15 Inleidinge tot de Hollandsche Rechts-Geleerdheid, III, 19, 16. 
'Maar in Holland en de Nabuyrige plaatsen is een gemenen regel, dat huyr gaat voor koop, en sonder onderscheid, niet alleen de Erfgenamen van den afgestorven, maar selfs den koper of making-beurder de huyr van sijn voorzaat moet voldoen. ${ }^{16}$

Het is naar dit 'oud-Hollandse recht' ('huur gaat voor koop') dat de Hoge Raad in zijn arresten aan het einde van de $19^{\mathrm{e}}$ eeuw en in de eerste helft van de $20^{\mathrm{e}}$ eeuw verwees voor de uitleg van art. 1612 OBW. ${ }^{17}$ Voor sommigen was zo'n verwijzing van de Hoge Raad naar het 'oud-Hollandse recht' aan het einde van de $19^{\mathrm{e}}$ eeuw vanzelfsprekend. Volgens de bekende Haagse advocaat A. de Pinto (1811-1878) in zijn Handboek tot het Burgerlijk Wetboek had de Nederlandse wetgever bij het opstellen van het Burgerlijk Wetboek een beroep gedaan op 'oude Nederlandsche wetgeving', indien in het wetboek iets moest worden opgenomen, 'wat aan de zeden en gewoonten van het volk ontleend was'. Het was niet twijfelachtig 'dat alsdan het 'oud-Hollandsch regt' datgene geweest is, waartoe men grootendeels zijne toevlugt genomen heeft.' De Franse Code civil was echter - dat wel 'de eerste en allervoornaamste bron' waaruit de wetgever van 1838 had geput. ${ }^{18}$

\section{De codificatiegeschiedenis en achtergrond van art. $1612 \mathrm{OBW}$}

De Nederlandse wetgever heeft in art. 1612 OBW een andere formulering gekozen dan de Franse in het daarmee corresponderende art. $1743 \mathrm{Cc}$ (dat overigens slechts gold voor de huur van huizen en landerijen). De Franse bepaling luidde als volgt: 'Si le bailleur vend la chose loueé, l'acquéreur ne peut expulser le fermier ou le locataire qui a un bail authentique ou dont la date est certaine (...). ${ }^{19}$ Het artikel is overgenomen uit de Loi concernant les biens et usages ruraux et la police rurale (de Code Rural) van 6 oktober 1791. Deze wettelijke maatregel was een uitvloeisel van de Franse revolutie. Zij hing samen met de

16 S. van Leeuwen, Het Rooms-Hollands-Regt, Amsterdam: Hendrik en de Weduwe van Dirk Boom 1686, IV, 21, 6 (p. 393). Vgl. J. van der Linden, Regtsgeleerd, Practicaal, en Koopmans Handboek, Amsterdam: Johannes Allart 1806, p. 165: 'huur gaat voor koop'. Zie E. Schrage, 'Locatio conductio', in: R. Feenstra und R. Zimmermann (Ed.), Das römisch-holländische Recht. Fortschritte des Zivilrechts im 17. und 18. Jahrhundert, Berlijn: Duncker \& Humblot 1992, p. 258 e.v.

17 In Utrecht gold vanaf 1659 het uitgangspunt 'koop breekt geen huur'. Zie P.J. Verdam, RomeinsUtrechts privaatrecht (1997), p. 85-87. Alleen de Friezen zouden vasthouden aan het strikte Romeinse recht. Het Hof van Friesland heeft echter aan het einde van de $18^{\mathrm{e}}$ eeuw gebroken met de regel koop breekt huur. Zie J.H.A. Lokin, C.J.H. Jansen, F. Brandsma, Het Rooms-Friese recht. De civiele rechtspraktijk van het Hof van Friesland in de $17^{e}$ en $18^{e}$ eeuw, Hilversum: Verloren 1999, p. 166 e.v.

18 A. de Pinto, Handleiding tot het Burgerlijk Wetboek, Tweede gedeelte. Aanteekeningen, vijfde druk, Utrecht: C. van der Post 1875, p. 3-4. Hij verwees onder andere in zijn Handboek naar De Groot en Van Leeuwen.

19 Indien de verhuurder het verhuurde goed verkoopt, kan de koper de pachter of de huurder die een huur heeft, vastgelegd in een authentieke akte of met een vaste dagtekening, niet uit het gehuurde goed zetten (...). 
afschaffing van allerlei misbruiken op het platteland. De pachter was onvrij en ongelijk. Hij was sterk afhankelijk van de luimen van de adellijke of geestelijke landheer. De Franse wetgever van 1804 heeft deze, specifiek op de pachter gerichte en op de landbouw afgestemde regeling veralgemeend voor alle pachten en huren, behalve dan dat de huurovereenkomst moest zijn aangegaan bij authentieke akte of een vaste dagtekening moest hebben. ${ }^{20}$

Zoals uit het bovenstaande duidelijk wordt, is art. 1612 OBW dus geen 'vertaling' van art. $1743 \mathrm{Cc}$. Vermoedelijk is het Ontwerp-Kemper uit 1820 de bron waaruit de wetgever van 1838 heeft geput voor de tekst van de bepaling (art. 2605; een tekst die weer is ontleend aan art. 2981 Ontwerp-1816). De eerste uitleggers van art. 1612 sloten wat betreft zijn uitleg echter aan bij de Franse context. De Pinto schreef dat het voorschrift voornamelijk was gemaakt in het belang van de landbouw. De 'landman' zou zich met veel meer vlijt en ijver op de bebouwing van het gehuurde land toeleggen, als hij zeker wist dat hij de vruchten van zijn arbeid zou oogsten en hij niet hoefde te vrezen door een nieuwe eigenaar van zijn land te worden verjaagd. De regeling was bovendien billijk, omdat een koper vooraf kon onderzoeken of en voor hoe lang het goed was verhuurd. Hij kon zich daarnaar gedragen. ${ }^{21}$ De Groningse hoogleraar G. Diephuis (1817-1892) sloot zich bij De Pinto aan. Hij meldde dat art. 1612 in het belang van de huurder was opgesteld, 'en daarbij tevens in het belang van den landbouw in het bijzonder en van het maatschappelijk verkeer in het algemeen'. De bepaling was bovendien redelijk, omdat een door partijen deugdelijk gesloten overeenkomst niet door een handeling van een van de partijen van haar kracht beroofd diende te kunnen worden. Voor de koper van het verhuurde goed was zij ten slotte niet onrechtvaardig of hard, omdat hij vooraf kon onderzoeken of het goed dat hij dacht te kopen verhuurd was. Bovendien kon hij de verkoper aanspreken, als hij zijn verplichtingen niet nakwam. ${ }^{22}$ Ook de Groningse hoogleraar N.K.F. Land (1840-1903) zocht nog aansluiting bij de ideeën van de Franse wetgever van 1804: 'De Fransche wetgever heeft met art. 1743 de belangen van landbouw en nijverheid willen dienen, en de onze heeft dat stelsel gevolgd, maar eenigszins andere woorden gekozen.' ${ }^{23}$ Bij Kamphuisen ten slotte verdween de verwijzing naar de belangen van de landbouw naar de achtergrond. Hij zag als grondslag van art. 1612 OBW (evenals overigens van art. $1743 \mathrm{Cc}$ ) 'overwegingen van opportuniteit en billijkheid', waarbij volgens hem kennelijk de opportuniteit de overhand had: 'Men moet het artikel zien als een zuiver uit opportuniteitsoverwegingen opgenomen bepaling, die dus hoofdzakelijk teleologisch moet worden uitgelegd.' ${ }^{24}$

20 Cerutti, 'De rechtsgeschiedenis van art. 1612 BW', p. 56; L.M. de Hoog, De prioriteitsregel in het vermogensrecht, Ars Notariatus 167, Deventer: Wolters Kluwer 2018, p. 214 e.v.

21 De Pinto, Handleiding tot het Burgerlijk Wetboek, II, § 920 (p. 612).

22 G. Diephuis, Het Nederlandsch Burgerlijk Regt, XII, Groningen: J.B. Wolters 1889, p. 160.

23 N.K.F. Land, Verklaring van het Burgerlijk Wetboek, V, $2^{\mathrm{e}}$ druk, herzien door C.W. Star Busmann, Haarlem: De Erven Bohn 1915-1932, p. 182.

24 Asser/Kamphuisen, Verbintenissenrecht, p. 260, p. 262 (citaat). Hij verwees overigens op p. 259 op de onbillijkheid van de regel koop breekt huur: de huurder kon dan zo maar 'uit zijn genot' worden verdreven door een vrijwillige handeling van de verhuurder. Daarnaast was deze regel in strijd met het 
Wat was de juridische constructie van art. 1612 OBW in het licht van de beginselen van het burgerlijke recht? Diephuis poneerde in zijn eerste commentaar Het Nederlandsch Burgerlijk Regt uit 1851 dat het feit dat de huurder niet verplicht kon worden tot ontruiming 'een uitvloeisel' was van het beginsel, 'dat niemand meer regt aan een' ander kan overdragen, dan hij zelf heeft, en eene uitdrukkelijke erkenning, dat de kooper, die ten aanzien van het geheele goed in de plaats van den verkooper treedt, het regt van den huurder moet eerbiedigen, en ook gebonden is aan de verpligtingen, die de verkooper als verhuurder ten aanzien van het verkochte goed jegens den huurder had. ${ }^{25}$ De Utrechtse hoogleraar C.W. Opzoomer (1821-1892) was er als de kippen bij om op de onhoudbaarheid van het eerste deel van Diephuis' stelling te wijzen. ${ }^{26}$ Het door Diephuis' aangevoerde hoofdbeginsel, 'welks waarheid ontwijfelbaar is', had betrekking op zakelijke rechten, terwijl Diephuis uitdrukkelijk aangaf dat het recht van de huurder een persoonlijk recht was. 'De bepaling dus, dat de verhuring niet op den successor singularis [de opvolger onder bijzondere titel] van den verhuurder, den kooper, overgaat, was niets anders dan een gevolg daarvan, dat verhuring geen zakelijk recht deed ontstaan, maar alleen een persoonlijke verbintenis. ${ }^{27}$ Diephuis kon deze sneer van Opzoomer niet over zijn kant laten gaan. Hij nam in deel XII van zijn opus magnum Het Nederlandsch Burgerlijk Regt afstand van zijn eerdere kanttekening: 'Ik zou hierbij liever niet willen aanvoeren, dat niemand meer of een beter regt aan een ander kan overdragen, omdat dit meer bepaaldelijk op zakelijke regten en de gesteldheid daarvan ziet.' 28

In 1896 gaf de Hoge Raad in aansluiting bij 'het oud-Hollandsche recht' de constructie van art. 1612 OBW als volgt weer: 'dat door verkoop van het verhuurde, tenzij het tegendeel bedongen is, de rechten en verplichtingen des verhuurders van rechtswege op den kooper overgaan, even alsof deze onder algemeenen titel aan den verkooper opvolgde (...).'29

algemeen belang, in het bijzonder van de landbouw, omdat de pachter ervan werd weerhouden het land met grote kosten te verbeteren. Vandaar dat de rechtsgeschiedenis in de loop van de tijd steeds weer pogingen zag om de regel koop breekt huur in zijn tegendeel te doen verkeren.

25 G. Diephuis, Het Nederlandsch Burgerlijk Regt, naar de volgorde van het Burgerlijk Wetboek, zevende deel, Groningen: J.B. Wolters 1851, nr. 430, p. 290. Diephuis' redenering sloot enigszins aan bij die van de $18^{\mathrm{e}}$-eeuwse natuurrechtsjuristen (zie noot 11). Zij was ook aan te treffen bij $19^{\mathrm{e}}$-eeuwse Franse juristen als Charles Aubry (1803-1883) en Frédéric-Charles Rau (1803-1877) in hun Cours de droit civil français, twee vertegenwoordigers van de (legistische) Ecole de l'Exégèse. Zie D. Deroussin, Histoire du droit des obligations, Parijs: Economica 2007, p. 264.

26 Diephuis en Opzoomer waren voortdurend met elkaar in debat en niet altijd op even vriendelijke wijze. Zie J.H.A. Lokin, De Groninger Faculteit der Rechtsgeleerdheid (1596-1970), Den Haag: Boomjuridisch 2019, p. 302 e.v.

27 C.W. Opzoomer, Het Burgerlijk Wetboek, verklaard, VIII, 's-Gravenhage: Belinfante 1891, p. $352-353$.

28 Diephuis, Het Nederlandsch Burgerlijk Regt, XII, p. 163. Volgens De Hoog, De prioriteitsregel in het vermogensrecht, p. 214 e.v. is het recht van de huurder op geen enkele manier onder de toepassing van de prioriteitsregel te brengen.

29 HR 20 november 1896, W. 1906/6882, p. 1. Ook HR 29 maart 1897, W. 1897/6937, p. 2 en HR 21 mei 1906, W. 1906/8368, p. 1. Star Busmann in Land/Star Busmann, Verklaring van het Burgerlijk Wetboek, V, p. 184 (en in noot 3) vond dat de zinsnede 'even alsof deze onder algemeenen titel aan den verkooper opvolgde' aanleiding gaf tot misverstand. De koper volgde de verkoper onder bijzondere titel op. De 
Overigens ging het niet - zoals uit een uitspraak van 12 jaar later naar voren kwam - om het moment van de verkoop, maar om dat van de eigendomsoverdracht. ${ }^{30}$ Volgens de Utrechtse hoogleraar W.L.P.A. Molengraaff (1858-1931) en zijn opvolger C.W. Star Busmann (1878-1966) waren de rechten en verplichtingen van de verhuurder jegens de huurder verknocht aan de eigendom van het gehuurde, zodat met de overgang van de eigendom tevens de verbintenissen jegens de huurder overgingen. Zij spraken daarom van kwalitatieveverbintenissen, verbintenissen aangegaan in de hoedanigheid van eigenaar. Art. 1612 OBW was - aldus Star Busmann - daarom te beschouwen als een uitbreiding van art. $1354 \mathrm{OBW}^{31}$, 'in zoover ook de verplichtingen, met betrekking tot de zaak aangegaan, op den rechtsverkrijgende onder bijzonderen titel overgaan.' 'Deze uitlegging is geheel in overeenstemming met de behoeften van het verkeer, hetwelk eischt, dat de huurder om nakoming van het huurcontract te verkrijgen zich niet heeft te wenden tot den oorspronkelijken verhuurder, maar zich moet houden aan den tegenwoordigen eigenaar, die de beschikking heeft over het verhuurde goed (...). ${ }^{32}$

Uit latere rechtspraak van de Hoge Raad kwam echter naar voren dat niet alle verplichtingen van de verhuurder jegens de huurder op de koper overgingen. Art. 1612 OBW was namelijk - in de woorden van het college - een afwijking van de algemene regel van art. 1376 OBW dat overeenkomsten alleen van kracht zijn tussen handelende partijen. Daarom was uitsluitend sprake van een opvolging in de rechten en plichten 'welke naar de omschrij ving van art. 1584 OBW betreffen het doen hebben van het genot eener zaak gedurende eenen bepaalden tijd en tegen eenen bepaalden prijs'. Volgens Star Busmann in zijn noot onder het arrest was de verwijzing naar art. 1584 dat alleen de essentialia van de huurovereenkomst bevatte, nietszeggend. ${ }^{33}$ De grens tussen wat wel en wat niet tot de huur behoorde, was echter moeilijk te trekken. Volgens Veegens/Oppenheim moest de rechter daarom de strekking van art. 1612 OBW in het oog houden: het belang van de huurder: 'dat daarom steeds aan de opvatting, waarbij de huurder het meeste baat vindt, de voorkeur

Hoge Raad had beter de tekst van art. 2605 Ontwerp-BW ('als of hij zelf de verhuring gedaan had') kunnen volgen.

30 Zie HR 13 november 1908, W. 1908/8764.

31 'Men wordt verondersteld bedongen te hebben voor zich zelven, en voor zijne erfgenamen en regtverkrijgenden, ten ware het tegendeel uitdrukkelijk bepaald zij, of uit den aard der overeenkomst mogt voortvloeien.'

32 Land/Star Busmann, Verklaring van het Burgerlijk Wetboek, V, p. 184-185; W.L.P.A. Molengraaff, Leidraad bij de Beoefening van het Nederlandsche Handelsrecht, vierde druk, Haarlem: De Erven Bohn 1919, p. 287-288. Ook J.Ph. Suijling, Inleiding tot het Burgerlijk Recht, $2^{\mathrm{e}}$ stuk-1 ${ }^{\mathrm{e}}$ gedeelte, Haarlem: De Erven Bohn 1934, nr. 15, p. 22-23. Over art. 1354 OBW: J.R. Beversluis, Enige aspecten van de kwalitatieve verbintenis, Den Haag: Boom Juridische uitgevers 2009.

33 HR 5 januari 1923, W. 1923/11021, p. 1. In casu ging het om een koopbeding in de huurovereenkomst. $\mathrm{Zij}$ gaf de huurder het recht het gehuurde na een tijd te kopen. Het koopbeding was volgens Star Busmann een onafscheidelijk onderdeel van de huurovereenkomst. De HR ging niet om: zie HR 6 juli 1929, W. $1929 / 11988$. 
gegeven moet worden.' ${ }^{34}$ Kamphuisen verwierp de opvatting van de Hoge Raad. Volgens hem moest de gehele huurovereenkomst met alle bedingen in stand blijven. Over de vraag of een beding rechtstreeks op de huurverhouding betrekking had, bestond veel verschil van mening en bij een dergelijk vaag criterium was dat ook niet te vermijden. Zijn eigen opvatting had 'de billijkheid voor zich': de koper moest maar informeren naar de inhoud van de huurovereenkomst. Als hij dit had gedaan, kon hij zich nauwkeurig op de hoogte stellen van zijn rechten en verplichtingen. Als hij dit had nagelaten, moest hij de gevolgen ervan dragen. ${ }^{35}$ De Hoge Raad heeft - voor zover ik kan nagaan - de kwestie laten rusten.

\section{Is huur een zakelijk recht?}

Een van de vragen, die veelvuldig aan de orde kwam bij de bespreking van art. 1612 OBW, was de kwestie of huur een zakelijk recht was. De jurist die deze vraag met nadruk aan de orde stelde en positief beantwoordde, was Opzoomer. Hij vermeldde uitvoerig de twistgesprekken tussen de Franse juristen over het karakter van art. 1743 Cc. Vooral R.T. Troplong (1795-1869) was een krachtig bepleiter van het recht van de huurder als een (bijzonder) zakelijk recht dat niet in de numerus clausus van zakelijke rechten was terug te vinden. ${ }^{36}$ Volgens de meerderheid had de Code echter het recht van de huurder gelaten wat het was: een persoonlijk recht. Volgens weer andere juristen had de Franse wetgever zich helemaal niet bekreund om het persoonlijke of zakelijke karakter van rechten (ook niet van het recht van de huurder), 'hij lette enkel op de nuttigheid, het algemeen en het privaat belang'. Toen de Nederlandse wetgever art. 1612 voordroeg, hield hij het 'voor een met het Fransche artikel, slechts in uitdrukking iets gewijzigd en tegelijk van zijn beperkingen ontdaan, algemeen gemaakt'. Hij had zich niet uitgelaten over het persoonlijke of zakelijke karakter van de bepaling. Het spraakgebruik onder Nederlandse juristen over dit karakter was 'zoo onzeker mogelijk. De een spreekt reeds van een zakelijk recht, waar de ander er niet aan denken durft, dien naam te gebruiken.' ${ }^{37}$ Opzoomer achtte zich daarom bevoegd tot de volgende uitspraak:

'het beginsel, in het eerste lid van dit artikel uitgesproken, schoon aan het wezen der persoonlijke

34 J.D. Veegens/A.S. Oppenheim, Schets van het Nederlandsch Burgerlijk Recht, III, Verbintenissen, Bewijs en Verjaring, vierde druk, bewerkt door C.H.F. Polak, Haarlem: H.D. Tjeenk Willink 1934, p. 276-277. Zie ook S. van Brakel, Leerboek van het Nederlandse Verbintenissenrecht, II, tweede druk, Zwolle: W.E.J. Tjeenk Willink 1948, p. 98-99.

35 Asser/Kamphuisen, Verbintenissenrecht, p. 268-269. Hij wees erop, 'juist omdat men in deze materie zo aan het oud-Vaderlands recht schijnt te hechten', dat het Ontwerp-1820 in art. 2605 uitdrukkelijk bepaalde dat de nieuwe eigenaar in de plaats van de verhuurder trad, even als of hij zelf de verhuring had gedaan'.

36 Schrage, Koop breekt geen huur, p. 9; Deroussin, Histoire du droit des obligations, p. 263. Volgens Troplong had het recht van de huurder zowel droit de suite als droit de préférence.

37 Opzoomer, Het Burgerlijk Wetboek, verklaard, VIII, p. 361-362 (citaat), p. 365 (citaat). 
JANSEN, C.J.H.

betrekking uit de overeenkomst van huur en verhuur geboren geen afbreuk doende, verleent toch, op gronden van nut en billijkheid aan den huurder in zoover iets dat aan het bezit van een zakelijk recht doet denken, dat hij door den kooper van het gehuurde goed niet tot ontruiming kan worden gedwongen. De kooper, wel verre van dien dwang tegen hem te kunnen uitoefenen, komt met dien koop tot hem in dezelfde betrekking, waarin de verkooper tot hem stond, alsof hij van dezen niet de "successor singularis", maar de "successor universalis" was. (....). 38

Volgens Opzoomer werd de huurder tegen een derde dus zo beschermd als hij zou worden beschermd, wanneer hij door zijn huur een zakelijk recht had gekregen. Wat hij met deze woorden precies bedoelde (had het recht van de huurder alleen droit de suite of ook andere kenmerken van een zakelijk recht, zoals droit de préférence?), wordt uit zijn commentaar niet duidelijk. ${ }^{39}$ Diephuis maalde daar niet om. Hij achtte Opzoomers duiding van het recht van de huurder als zakelijk 'onjuist'. Art. 1612 OBW gaf de huurder niet het recht om de zaak van een iedere bezitter op te vorderen, maar zei alleen dat de verkoop de huur niet verbrak. De koper kon daarom de huurder niet verplichten tot ontruiming. De huurder bleef bovendien al het recht behouden dat de verhuur hem gaf. ${ }^{40}$ Opzoomer noemde deze uitlegging van Diephuis 'verkeerd'. Laatstgenoemde plaatste art. 1612 OBW en art. 1743 Cc naast elkaar, alsof er geen verschil tussen de twee bepalingen bestond. Dat de koper de huurder niet kon dwingen tot ontruiming, volgde uit de woorden 'ne peut expulser' in art. $1743 \mathrm{Cc}$. In art. 1612 waren de bewoordingen veel algemener. Art. 1612 hoefde bovendien de huurder geen recht te geven tegenover de verhuurder. Dat lag in de aard van de huurovereenkomst. ${ }^{41}$ Diephuis bestreed Opzoomers opvatting opnieuw uitvoerig. Voor de vestiging van zakelijke rechten was een vestigings- of leveringshandeling nodig. Het recht van de huurder ontstond uit een overeenkomst, die alleen persoonlijke rechten in het leven riep, 'maar regtstreeks ook geene andere'. Diephuis beklemtoonde:

'Wat de bepaling betreft van art. 1612 (art. 1743 C.N.), waarop de leer van het zakelijk regt voornamelijk wordt gebouwd, zij brengt volstrekt niet mede, dat de huurder zijn regt als zoodanig tegen iederen houder kan doen gelden en het goed van elken bezitter opvorderen. Zoodanig regt is hem nergens toegekend (...).'

38 Opzoomer, Het Burgerlijk Wetboek, verklaard, VIII, p. 366. Ook C.W. Opzoomer, Het Burgerlijke Wetboek. Aanteekening op de artikelen die thans nog verklaring behoeven, III, Amsterdam: J.H. Gebhard 1852, p. 138: 'ik had dus regt tot de bewering, dat onze wetgever, ten gevolge der afwijking van het Romeinsche regt omtrent den invloed eener verkooping op vroegere verhuringen, door de huurovereenkomst inderdaad een zakelijk regt heeft doen ontstaan, maar dan ook tevens het verschil in wezen van het vruchtgebruik heeft opgeheven.'

39 Het recht van de huurder was volgens $§ 1095$ ABGB een zakelijk recht, als het was ingeschreven 'in die öffentlichen Bücher'. Wanneer het recht van de huurder niet was ingeschreven, moest hij wijken voor de nieuwe bezitter ( $\$ 1120$ ABGB).

40 Diephuis, Het Nederlandsch Burgerlijk Regt, naar de volgorde van het Burgerlijk Wetboek, VII, nr. 430, p. 289-290.

41 Opzoomer, Het Burgerlijke Wetboek. Aanteekening op de artikelen die thans nog verklaring behoeven, III, p. 139. 
Art. 1612 OBW zou - aldus Diephuis - ook geen enkele betekenis hebben, als de huurder een zakelijk recht had gehad. De bepaling

'komt alleen te pas als zijn regt enkel een persoonlijk karakter heeft; maar nu laat zich dan ook uit hare opneming in de wet afleiden, dat de wetgever des huurders regt werkelijk aldus heeft beschouwd. ${ }^{42}$

Land volgde Diephuis: 'Dat huur geen zakelijk karakter heeft, moeten wij naar ons recht als vaststaande aannemen. De huurder had geen zakelijk recht op het gehuurde goed tegen elke derde, maar stond enkel in een persoonlijke rechtsbetrekking tot de verhuurder. Hij kon namelijk niet met een eigendoms- of bezitsvordering tegen een houder van de zaak optreden, maar alleen met een persoonlijke rechtsvordering de verhuurder en diens rechtsopvolgers aanspreken. Tot die rechtsopvolgers behoorde volgens de 'eenvoudige strekking' van art. 1612 de koper. ${ }^{43}$

Niet iedereen liet zich overtuigen door de woorden van Diephuis. Opzoomer kreeg bijval van een aantal auteurs. ${ }^{44}$ Veegens/Oppenheim/Polak schreef: 'Ik aarzel hoe haar (de vraag of huur een zakelijk recht was) te beantwoorden.' Het recht van de huurder schurkte qua rechtsgevolg wel heel dicht aan tegen het zakelijke recht. ${ }^{45}$ De meerderheid van de juristen verwierp echter het zakelijke karakter van het recht van de huurder. Volgens P. Scholten (1875-1945) was het nodig voor de kwalificatie van een recht als persoonlijk of zakelijk naar het 'geheel der regeling' te kijken. Hij wees er bijvoorbeeld op dat het recht van de huurder niet overdraagbaar was, niet voor beslag of verpanding vatbaar. 'Op zich zelf is dat zeker niet beslissend, voor de typeering van het geheel mag het meetellen.' 46

\section{Koop breekt geen huur en het 'Germaanse recht'}

Uit de betogen van Gilissen en Cerutti valt af te leiden dat de regel koop breekt geen huur

42 Diephuis, Het Nederlandsch Burgerlijk Regt, XII, p. 171 e.v. (citaat op p. 172).

43 Land/Star Busmann, Verklaring van het Burgerlijk Wetboek, V, p. 183.

44 Bijv. W.Th.C. van Doorn, 'Hoe moet geregeld worden de tenuitvoerlegging van vonnissen in burgerlijke zaken, inhoudende eene veroordeeling tot eene andere prestatie dan die eener geldsom? ', HNJV 1900I, p. 102. Was huur niet een zakelijk recht volgens ons BW? 'Ik ben zeer geneigd het toe te geven (...).' A.L.M. van Berckel, Het rechtskarakter der huur van onroerend goed volgens hedendaagsch Nederlandsch recht, diss. Amsterdam, Nijmegen: Boek- en kunstdrukkerij Geurts 1920, p. 103 en p. 127 e.v.

45 Veegens/Oppenheim/Polak, Schets van het Nederlandsch Burgerlijk Recht, III, p. 277-278.

46 P. Scholten, Mr. C. Asser's Handleiding tot de Beoefening van het Nederlandsch Burgerlijk Recht, tweede deel-Zakenrecht, $8^{\mathrm{e}}$ druk, met medewerking van G.J. Scholten, Zwolle: W.E.J. Tjeenk Willink 1945, p. 34-35; zie ook L.C. Hofmann, Het Nederlandsch Zakenrecht, derde druk, Groningen-Batavia: J.B. Wolters 1944, p. 10: 'Men zal huurvan onroerend goed en pacht dus, ondanks zekere eigenschappen van een zakelijk recht, als persoonlijk moeten beschouwen.' Asser/Kamphuisen, Verbintenissenrecht, $\mathrm{p}$. 202. 'De huurovereenkomst geeft de huurder slechts een persoonlijk recht; hoewel zijn positie ten opzichte van de verhuurde zaak wel enige zakelijke trekken heeft, is het onjuist hem een zakelijk recht toe te kennen.' Over pacht als zakelijk recht: E.M. Meijers, Algemene leer van het Burgerlijk Recht, Deel I, De Algemene begrippen van het Burgerlijk Recht, Leiden: Universitaire Pers Leiden, p. 277. 
of huur gaat voor koop 'Germaansrechtelijke' wortels kende. Zij lieten tegelijkertijd zien dat de 'Romeinsrechtelijke' regel koop breekt huur in veel 'Germaanse' gebieden die nog niet waren beïnvloed door de receptie van het Romeinse recht, de 'autochtone' regeling was en soms was veranderd in haar tegendeel: koop breekt geen huur. ${ }^{47}$ In de loop van de $19^{\mathrm{e}}$ eeuw groeide de belangstelling voor het 'Germaanse' recht, niet alleen in de Duitse landen, maar ook in Nederland. Een mooi voorbeeld daarvan was aan te treffen in het NJVpreadvies van P. van Bemmelen (1828-1892) uit 1890 over de uitleg van art. 2014 OBW ('bezit geldt als volkomen titel'). Hij besprak daarin het 'Germaansche' stelsel. Voorafgaande aan zijn inhoudelijke beschouwingen makte Van Bemmelen enkele opmerkingen over het 'Germaanse' recht, waarvan in zijn tijd een zekere bekoring uitging, 'in geringere mate, maar eenigszins als voorheen [van] het nu wel wat uit de mode geraakte romeinsche recht'. 'Het germanendom is thans zeer in eere, omdat het vooraan staat in de wereldheerschappij; en vele Nederlanders stellen er prijs op, dat zij, als afstammelingen der Nederfranken, Friezen of Nedersaksers, Germanen zijn.' De 'Germaanse' rechtsbeginselen waren 'hoogstaander' en pasten beter 'bij de hoogere europeesche beschaving dan de romeinsche'. ${ }^{48}$ Van Bemmelens opmerking over het hoogstaande karakter van de 'Germaanse' rechtsbeginselen bracht de Amsterdamse advocaat en het NJV-erelid J.A. Levy (1836-1920) ertoe het Romeinse eigendomsbegrip te associëren met 'star' en met 'koud en naakt egoïsme', terwijl het Germaanse eigendomsrecht volgens hem uitging van solidariteit en van een 'zedelijke' heerschappij over de zaak. ${ }^{49}$

Toen de Duitse wetgever in zijn eerste ontwerp van een nieuw Duits Burgerlijk Wetboek ( $\S$ 509) koos voor de Romeinsrechtelijke regel 'koopt breekt huur' vanwege zijn gehechtheid aan het dogma dat een overeenkomst (zoals het huurcontract) slechts persoonlijke rechten en plichten in het leven riep, hekelde H.L. Drucker (1857-1917), de geestelijke vader van de Nederlandse Wet op de arbeidsovereenkomst (1907/1909), dan ook deze keuze. Hij verweet de Duitse wetgever dat hij gevangen zat in Romeins 'doctrinarisme' en de maatschappelijke werkelijkheid volledig uit het oog had verloren. Het dogma had de plaats

47 Cerutti, 'De rechtsgeschiedenis van art. 1612 BW', p. 49 e.v.; Gilissen, "Huur gaat voor koop” in het oud-Belgische recht', p. 287 e.v. (koop gaat voor huur (tenzij een afwijkende bepaling) gold in Sluis, Aardenburg, Diksmuide en Nieuwpoort, p. 295 e.v.; het recht van Namen volgde de regel koop breekt huur, p. 307 e.v.; het 'Luikse' recht en het 'Limburgse recht gingen uit van huur gaat voor koop, p. 308 e.v., p. 311 e.v.; het Luxemburgse recht volgde weer de 'Romeinsrechtelijke' regel koop breekt huur, p. 312 e.v.).

48 P. van Bemmelen, 'Moet, ten aanzien van roerend goed, de wet uitgaan van den regel, dat eigenaar of pandhouder is hij, die als zoodanig bezit, behoudens de verplichting van elken houder tot teruggaaf van het goed aan hem, die het buiten zijnen wil is kwijtgeraakt', HNJV 1890-I, p. 3. Hij vond overigens dat art. 2014 OBW niet van Germaanse oorsprong was, maar een 'allertreurigst' product van 'ondoordachte moderne wetgeving' (p. 8). L.C. Hofmann, Hand muss Hand wahren in het oud-Germaanse en oudDuitsche recht, Leiden: Eduard IJdo, 1927, p. 1 schreef echter dat het algemeen was aanvaard dat het beginselachter 2014 OBW van 'Germaanschen oorsprong' was. Vgl. A.F. Salomons, 2014 tot 1950. De geschiedenis tot 1950 van de vertrouwensbescherming bij overdracht van roerende zaken door een beschikkingsonbevoegde, Deventer: Kluwer 1997, p. 3-4, p. 17 e.v. 


\section{HERKOMST EN BETEKENIS VAN ARTIKEL 1612 OUD BURGERLIJK WETBOEK}

ingenomen van het onbevangen waarnemen van de feiten en die logen er in Druckers tijd niet om. Het gehele privaatrecht moest - gelet op de werkelijkheid van de industriële revolutie en de daaruit voortvloeiende sociale problemen op het gebied van woningnood, volksgezondheid en arbeidersbescherming e.d. - van sociale opvattingen worden doortrokken. ${ }^{50}$ Drucker trad met zijn voorkeur voor een 'sociaal' privaatrecht en zijn kritiek op het BGB, in het bijzonder op de keuze voor de regel koop breekt huur, in de voetsporen van de Duitse hoogleraar O. von Gierke (1841-1921). Die betoogde in zijn beroemd geworden rede Die soziale Aufgabe des Privatrechts (1889) dat er geen grotere aanval op de 'soziale Aufgabe des heutigen Privatrechts' zou zijn dan als het nieuwe burgerlijke wetboek het 'romanistische' adagium 'Kauf bricht Miethe" zou bevatten. Deze regel paste goed bij het 'individualistische' Romeinse recht, maar allerminst bij het 'sociale' Germaanse recht. Gierke stond niet alleen in zijn aanval op $\S 509$. De Duitse wetgever is overstag gegaan. Het BGB van 1900 kende in $\S 571$ het uitgangspunt koop breekt geen huur. ${ }^{51}$

De kritiek op het Romeinse recht als asociaal en 'egoïstisch' verstomde in de eerste helft van de $20^{\text {e }}$ eeuw niet. Een van de meest 'rabiate' vertegenwoordigers van dit standpunt was de jurist Antoon (A.C.B.) Arts (1873-1955), conservatief Rooms-Katholiek en hoofdredacteur van de Nieuwe Tilburgsche Courant en het Overijselsch Dagblad. Hij schreef bijvoorbeeld in laatstgenoemde krant naar aanleiding van de opening van de Katholieke Universiteit in Nijmegen in 1923:

'Tot nog toe werden onze juristen onder het sociaal vriespunt gehouden in de koelkamers van het Romeinsch recht. Prachtig van systeem, ijskoud van geest. Hadden zij kennis gekregen van het Canonieke recht, waarin naast het beste van het Romeinsche formeele ook het Germaansch-christelijke is opgenomen, dan zouden hun sociale opvattingen heel wat milder en christelijker zijn. ${ }^{52}$

Elders schreef Arts dat Nederland nog steeds leefde onder de heerschappij van het Romeinse recht.

'Het recht voor de machtigen en rijken bijzonder geschikt, voor de kleinen echter zeer drukkend. Dit is dan ook de oorzaak, dat het christelijk-germaansche recht, zooals dat in de $12^{\mathrm{e}}, 13^{\mathrm{e}}$, en $14^{\mathrm{e}}$ en in de $15^{\mathrm{e}}$ eeuw zelfs nog in onze landen gold, met het romeinsch recht werd bestreden door allen die een onbeperkte vrijheid wenschten om goed en goederen te verkrijgen, ook door uitbuiting des volks. ${ }^{53}$

50 H.L. Drucker, Begrip en dogma in de rechtswetenschap, Haarlem: De Erven Bohn 1889, p. 17-18.

51 O. von Gierke, Die soziale Aufgabe des Privatrechts, herdruk, Frankfurt am Main: Vittorio Klostermann 1948, p. 21. Zie S. Hofer, Freiheit ohne Grenzen? Privatrechtstheoretische Diskussionen im 19. Jahrhundert, Tübingen: Mohr Siebeck 2001, p. 143 e.v. Ook: T. Repgen, Die soziale Aufgabe des Privatrechts. Eine Grundfrage in Wissenschaft und Kodifikation am Ende des 19. Jahrhunderts, Tübingen: Mohr Siebeck 2001, p. 231 e.v.

52 'De politiek van den dag', Overijselsch Dagblad 19 januari 1923, voorpagina.

53 A. Arts, 'Handelsmoraal en Recht', Nieuwe Tilburgsche Courant (NTC) 27 juni 1930, voorpagina (Overijselsch Dagblad 28 juni 1930, voorpagina).Zie ook 'En toch...', NTC 5 oktober 1938, voorpagina. 
Arts heeft zijn strijd voor meer aandacht voor het 'Christelijk-Germaanse' recht naast het Romeinse recht in de opleiding van de juristen voortgezet tot in de bezettingsjaren. Hij wees erop dat zijn idee niets te maken had met de 'nieuwe tijden' waarin Nederland was terecht gekomen. Evenals Levy schreef Arts dat het eigendomsrecht volgens christelijk-germaans recht een zedelijke heerschappij over de zaak inhield, naar het romeins-heidense recht was het recht echter een absoluut recht van ge- en ook misbruik van een zaak. 'Hierdoor werd het gemeenschapsgevoel, het gevoel van samenhoorigheid vernietigd en werd de deur voor winzucht zonder grenzen opengezet. ${ }^{54}$ De ideeën van Arts - anti-NSB en antinationaalsocialist - waren koren op de molen van nationalsocialistische juristen. $\mathrm{Zij}$ hielden een pleidooi voor de vervanging van het op het Romeinse recht gebaseerde BGB (het Duitse Burgerlijke Wetboek) door het Germaanse recht en voor de invoering van een Volksgesetzbuch. ${ }^{55}$ Dat idee sprak ook Nederlandse 'volkse' juristen aan. Volgens de Amsterdamse hoogleraar in het oud-vaderlandse recht L.J. van Apeldoorn (1886-1979) drong de bestudering van het Romeinse recht de beginnende jurist in een individue elkapitalistische en 'volksvreemde' richting. Hij pleitte daarom voor de introductie van een nieuw vak, de historische ontwikkeling van het recht, waarin het Romeinse recht, het Germaanse recht en het 'Kanonieke' recht aan bod konden komen. 'Men zal het Romeinsche recht voortaan moeten beoefenen, niet opdat het de grondslag van ons geldend recht blijve, maar opdat het ophoude dit te zijn. ${ }^{56}$

\section{Slotopmerkingen}

De Hoge Raad koos - geïnspireerd door het proefschrift Huur en vervreemding (1880) van zijn latere raadsheer (1902-1908, 1911-1921), A.P.L. Nelissen (1851-1921) - aan het einde

54 A. Arts, 'Terug naar het Christelijk-germaansche', NTC 5 oktober 1940, voorpagina; A. Arts, 'Iets over oud-christelijk germaansch recht', NTC 5 juni 1941, voorpagina; A. Arts, 'Recht en onrecht', NTC 11 juni 1941; A. Arts, 'Meer bedorven dan de rechtspraak alleen', NTC 12 juni 1941, voorpagina (citaat). Arts, gepromoveerd in Amsterdam bij de staatsrechtsgeleerde A.A.H. Struycken (1873-1923), was gecharmeerd van de conservatief-katholieke priester W. Lutkie (1887-1968), fascistisch en bewonderaar van Mussolini, maar anti-NSB. Hij schreef ook in Lutkie's blad Aristo. Arts verzamelde zijn artikelen uit de NTC in een boek: Van blad tot boek. Verzameld Werk van Dr. A.C.B. Arts met inleidingen van Professor Mr. W. Pompe en Wouter Lutkie, Pr., Tilburg: Nieuwe Tilburgsche Courant 1937.

55 Zie L.J. van Apeldoorn, 'De fundamenten van een grootsch bouwwerk. Het Duitsche Volkswetboek. Grondregels en Boek I', Het Rechtsfront 1943, p. 18, p. 26-27, p. 37-39, p. 45-46, p. 54-55; H. Westra, 'Het plan voor het nieuwe Duitsche Volkswetboek', Nieuw Nederland 1941, p. 431-434 en 'Een Duitsch "Volkswetboek", Het nieuwe Volk 8 maart 1941, p. 7.

56 Zie L.J. van Apeldoorn, De wedergeboorte van het volksrecht, Leiden: Nenasu 1941, p. 30 (citaat). Vgl. K. Luig, 'Römische und germanische Rechtsanschauung, individualistische und soziale ordnung', in: J. Rückert und D. Willoweit (Hrsg.), Die deutsche Rechtsgeschichte in der NS-Zeit: ihre Vorgeschichte, ihre Nachwirkungen, Tübingen: Mohr Siebeck 1995, p. 95 e.v. Over Van Apeldoorn en het Romeinse recht: T.J. Veen, 'Van Apeldoorn en het Romeinse recht', NJB 1991, p. 1654-1660 en T. Veen, “'Ongezonde kost'. L.J. van Apeldoorn over de rechtsgeleerdheid onder Cras en zijn voorgangers (16411820)', in: E.O.G. Haitsma Mulier e.a. (red.), Athenaeum Illustre. Elf studies over de Amsterdamse Doorluchtige School 1632-1877, Amsterdam: Amsterdam University Press 1997, p. 276 e.v. 
van de $19^{\mathrm{e}}$ eeuw voor een wets- en rechtshistorische uitleg van art. 1612 OBW. Het college deed voor de betekenis van deze bepaling een beroep op het 'oud-Hollandsche recht', in het bijzonder op het werk van De Groot, Groenewegen van der Made en Van Leeuwen. 57 In de beeldvorming van die tijd stamde de regel 'koop breekt geen huur' uit het 'Germaanse' recht, het tegenovergestelde adagium koop breekt huur uit het Romeinse recht. Later onderzoek van Gilissen en Cerutti heeft duidelijk gemaakt dat deze aanname slechts gedeeltelijk overeenkwam met de werkelijkheid. Uit hun nauwgezet bronnenonderzoek bleek dat het inheemse recht van voor 1500 vaak ook als uitgangspunt koop breekt huur kende. Dit uitgangspunt onderging onder invloed van de vaak niet nader omschreven werking van de billijkheid wijziging. De Hoge Raad greep in zijn uitspraken terug op 'het oud-Hollandse recht', anders gezegd het Rooms-Hollandse recht. Dit was allerminst het Germaanse recht dat de 'Germanisten' voor ogen stond, omdat het Rooms-Hollandse recht een product was van de receptie van het Romeinse recht. Zoals Cerutti terecht stelde, ging Kamphuisens afwijzing van ieder verband met het oud-vaderlandse recht te ver. De tekst van art. 1612 OBW ging via het Ontwerp 1820 wel degelijk terug op het Rooms-Hollandse recht. 58

Over de constructie van art. 1612 OBW ontstond verschil van mening tussen de twee Nederlandse privaatrechtelijke giganten van de $19^{\mathrm{e}}$ eeuw, Diephuis en Opzoomer. Het artikel leverde een aardige illustratie van de wijze waarop zij met elkaar discussieerden. Diephuis verklaarde aanvankelijk de binding van de koper van de verhuurde zaak aan de afspraken tussen verkoper/verhuurder en huurder met behulp van de nemo plus-regel, terwijl hij het recht van de huurder als een persoonlijk recht zag. Opzoomer achtte de visie van Diephuis - niet verrassend - verkeerd. Hij probeerde de binding te verklaren door de huurder een zakelijk recht toe te kennen, hetgeen Diephuis weer onjuist vond. Ieder dacht de billijkheid (en het nut) aan zijn zijde te hebben, Opzoomer wellicht nog meer dan Diephuis. Beide hoogleraren hadden hun medestanders.

De wetshistorische uitleg van art. 1612 OBW verdween na de Tweede Wereldoorlog naar de achtergrond. Kamphuisen bijvoorbeeld was voorstander van een teleologische uitleg van dit artikel. Hij wees erop dat iedere interpretatie moest staan in het licht van de strekking van deze bepaling: de bescherming van de huurder. Hij sloot met dit standpunt aan bij de lange ontwikkeling die het dogmatische uitgangspunt dat huur slechts persoonlijke rechten en plichten in het leven riep, heeft doorgemaakt. De rode draad hierin was steeds (meer) de

57 Niet alleen de Hoge Raad deed een beroep op 'het oud-Hollandsche recht.' Lagere rechters deden dat ook. Een mooi voorbeeld is te vinden in een uitspraak van de Rb Amsterdam van 13 maart 1907, $W$. $1907 / 8567$, p. 3-4. De rechtbank onderzocht in haar uitspraak in hoeverre het toonderpapier als geldig werd erkend voor en tijdens de totstandkoming van het BW van 1838. Uit de rechtsgeschiedenis bleek volgens de rechtbank dat in de Nederlanden een levendige fonds enhandel werd gedreven en dat op ruime schaal gebruik werd gemaakt van de toonderclausule. Zij baseerde zich op de Inleidinge van De Groot en de Theses Selectae Juris Hollandici et Zelandici (uitgegeven in 1800, herdrukt in 1860) van de Leidse hoogleraar D.G. van der Keessel (1749-1827). Ook deed de rechtbankeen beroep op de artt. 2298-2302 Ontwerp-1820.

58 Cerutti, 'De rechtsgeschiedenis van art. 1612 BW', p. 58. 


\section{JANSEN, C.J.H.}

bescherming van de huurder, van de 'Romeinen' tot nu. Art. 7:226 lid $1 \mathrm{BW}$ - een codificatie van de rechtspraak van de Hoge Raad uit vooral de eerste helft van de $20^{\mathrm{e}}$ eeuw - luidt als volgt:

Overdracht van de zaak waarop de huurovereenkomst betrekking heeft en vestiging of overdracht van een zelfstandig recht van vruchtgebruik, erfpacht of opstal op de zaak waarop de huurovereenkomst betrekking heeft, door de verhuurder doen de rechten en verplichtingen van de verhuurder uit de overeenkomst, die daarna opeisbaar worden, overgaan op de verkrijger.

C.J.H. Jansen ${ }^{59}$

NIJMEGEN

59 Corjo Jansen is hoogleraar Rechtsgeschiedenis \& Burgerlijk Recht aan de Radboud Universiteit Nijmegen. Hij is tevens voorzitter van het Nijmeegse Onderzoekscentrum Onderneming \& Recht. 